\section{INTERESTING DRINKING BEHAVIOUR OF CAPPED LANGUR (TRACHYPITHECUS PILEATUS) IN GIBBON WILDLIFE SANCTUARY, ASSAM}

\author{
D. Chetry, R. Medhi and P.C. Bhattacherjee
}

Animal Ecology and Wildlife Biology, Department of Zoology, Gauhati University, Guwahati, Assam 781014, India.

Gibbon Wildife Sanctuary $\left(26^{\circ} 45^{\prime} \mathrm{N} \& 94^{\circ} 25^{\prime} \mathrm{E}\right)$ in the Jorhal District of Assam is 1915.06ha in area (altitude range: $100-120 \mathrm{~m}$ ). During the month of May 1998 a dry spell hit the area around the Sanctuary. Most of the small ponds in the area dried up. Water level of most of the wells receeded to such levels that some of the wells had to be deepened. The well in the Forest Beat Office complex had also dried during that season. To mitigate the crisis the office staff dug the well further. A group of Rhesus Macaques (Macaca mulatta) was seen to visit the well regularly in search of water. Observing this, the forest staff kept a bucket full of water near the well. The Rhesus group came, looked around and drank water from the bucket. Then onwards, the forest staff regularly kept the bucket filled with water for the Rhesus group. On the third day, following the Rhesus group, one Capped Langur (Trachypithecus pileatus) troop whose home range fell near the Beat Office boundary was also seen drinking water from that bucket. In total, 15 such interesting drinking episodes of the Capped Langur troop was recorded during one month. After the rains started, the Capped Langur troop ceased to visit the Beat Office for water. This is really interesting because at Madhupur in Bangladesh 15 such episodes of drinking by Capped Langurs were recorded in 15 months (Stanford, 1991). Capped Langurs are generally reluctant to come down to two meters above the ground to drink water from tree trunks, excepting the lactating female with the young. Three of these 15 drinking bouts took place at the paddy field (Stanford, 1991). However, in the present case the troop walked over $200 \mathrm{~m}$ on ground and crossed the railway line, which runs through the Sanctuary to drink from the bucket.

\section{Acknowledgements}

We are thankful to the Indo-US Primate Project (Grant Agreement No. INT/WFS-22) for providing financial and technical support during the study period.

\section{Reference}

Stanford, C.B. (1991). The Capped Langur in Bangladesh: Behavioural Ecology and Reproductive Tactics. Contribution to Primatology Vol. 26, Karger, New York.

Received 27 August 2001; Revised received 12 December 2001

Finally accepted 9 August 2002

\section{RUMEN FISTULATION IN CHINKARA (GAZELLA BENNETTI)}

\author{
Makkena Sreenu ${ }^{1}$ and Jayaprakash ${ }^{2}$ \\ ${ }^{1}$ Assistant Professor in Surgery, Veterinary Clinical Complex, NTR College \\ of Veterinary Science, Gannavaram, Andhra Pradesh 521101, India. \\ ${ }^{2}$ M.V.Sc. Scholar, Department of Surgery and Radiology, College of \\ Veterinary Science, Tirupati, Andhra Pradesh 517502, India.
}

A three-year old female Chinkara was presented to the surgical ward with a history of anorexia for the last three days. It had had a fight with a male Chinkara and acquired a horn gore injury on its left lateral abdominal wall. Clinical examination revealed that all the physiological parameters were within the normal limit. An open wound on the left lateral abdomen parrallel to the last rib was observed. The wound showed oozing of ruminal fluid confirming fistula of the rumen. The depth of the wound was $6 \mathrm{~cm}$. To reconstruct the fistulous tract, laporotomy was performed under local infiltration analgesia with $2 \%$ Lignocaine. The site around the wound was prepared for a septic surgery. The animal was premedicated with Diazepam @ $0.25 \mathrm{mg} / \mathrm{kg}$ b.wt intramuscularly. Ketamine hydrochloride @ $3.5 \mathrm{mg} / \mathrm{kg}$ b.wt.was administered intramuscularly after 15 minutes of premedication.

The animal was restrained on its right lateral recumbency. A 6$\mathrm{cm}$ cutaneous incision was made parallel to the last rib and cutaneous wound. The abdominal muscles were separated bluntly along their muscle fibre direction. A nick incision was made on peritoneum to approach the underlying injured part. A $3-\mathrm{cm}$ injury along with adhesions between abdominal wall was observed. Adhesions around fistulous opening and abdominal wall were bluntly separated. The fistulous opening on the rumen was sutured with continuous Cushings and Lamberts suture pattern with No. 2 chromic catgut after freshening it. The peritoneum and abdominal muscles were sutured in a continuous lock stitch manner. The cutaneous wound was sutured with horizontal mattress pattern. Parenteral antibiotics were administered (Ampiclox $1 \mathrm{~g} \mathrm{i} / \mathrm{m}$ ) for five days. The cutaneous wound was daily dressed with Furacin ointment and the cutaneous sutures were removed on the ninth day. The animal made an uneventful recovery without gastro-intestinal tract abnormalities.

\section{Acknowledgements}

The authors are thankful to the authorities of the S.V. Zoological Park, Tirupathi for their kind cooperation in publishing this paper.

Received 22 December 2001; Finally accepted 2 September 2002 